\title{
IN THE VALLEY OF THE BLIND: A PRIMER ON JURY SELECTION IN A CRIMINAL CASE
}

\author{
Herald P. Fahringer* \\ I \\ INTRODUCTION
}

Jury selection is the most important part of any criminal trial. If a lawyer has a difficult case, but succeeds in obtaining a jury sympathetic with his client's cause, the chances of winning improve substantially. On the other hand, a client may have an excellent defense, but if he suffers the misfortune of having twelve antagonistic jurors, sometimes the skill of no lawyer can save him. In most cases, the defendant's fate is fixed after jury selection. Consequently, counsel's ability to select a favorable jury in a criminal case is of paramount importance. For this reason, jury selection has become the subject of more and more solemn studies and the focus of boundless curiosity among members of the legal profession.

Articles are coming forth in salvos' because recently an abundance of fresh information has been produced through the work of social scientists, lawyers, and psychologists. ${ }^{2}$ Their assembly has dispelled several myths that

\footnotetext{
* Practicing attorney, New York City and Buffalo, New York; Fellow, American College of Trial Lawyers; General Counsel, First Amendment Lawyers Association.

1. Bennett, Psychological Methods of Jury Selection in the Typical Criminal Case, 4 Crim. DeF. 24 (Mar.-April 1977); J. Murray \& J. Eckman, A Follow-up Study of Jury Selection (Sept. 1974) (paper presented to the annual meeting of the American Psychological Association in Montreal, Canada); Saks, Social Scientists Can't Rig Juries, 9 Psych. Today 48 (Jan. 1976); J. Van Dyke, Jury Selection Procedures (1977); A. Ginger. Jury Selfetion in Criminal Trials (1977); National. Jury Project, Jury Work: Systematic. Technlques (1979); Suggs \& Sales, Using Communication Clues to Evaluate Prospective Jurors, 20 ARIz. L. Rev. 629 (1978); Kennelly, Jury Selection in a Civil Case, 9 Trial Law. Guide 15 (1965); Schulman, A Systematic Approach to Successful Jury Selection, 2 Guldd Notes 13 (Nov. 1973): R. Blauner, The Sociology of Jury Selection, in Ginger, supra, at 443-74; Schulman, Shaver, Colman, Emrich \& Christie, Recipe for a Jury, Psych. Today, May 1973 , at 37 .

2. Organizations such as the National Jury Project have made some important discoveries in the field of jury selection. This small band of social scientists and lawyers, working out of makeshift quarters and operating behind the lines in such notable cases as the "Harrisburg Seven," the "Camden 28," the "Gainesville Eight," and the "Attica Rebellion" cases, have achieved some stunning results. By 1975, this remarkable group had fought its way into the mainstream of the American legal profession. They adopted the name The National Jury Project and have offices in New York, Atlanta, Minneapolis, Berkeley and Boston. Their impressive experiences, discoveries, and conclusions have recently been recorded in a distinguished study entitled, JURY WORK: SysTematic Techniques. Every trial lawyer in this country should be eager to read this volume and
} 
have grown up around jury selection in the United States. For instance, a lawyer's instincts about whether a certain class of jurors are preferable are not always reliable. In fact, most of the trial bar are willing to acknowledge that the approach of jury selection has been anything but scientific. It smacks of a modern alchemy full of jargon, superstition and mystification, but little real knowledge. All too often, it constitutes babbling an obligato of clichés in an ingratiating attempt to establish warm contact with the jurors. This "kamikaze" approach to choosing jurors uses some instinct and a little intuition with a dash of voodoo thrown in.

At the outset, it must be conceded that jury selection involves some guile on the part of lawyers. ${ }^{3}$ Lawyers announce to the panel that they want only jurors who will decide the case impartially, while, in fact, they want partisan jurors. Counsel is obliged to pick people who, by reason of their background, personality or attitudes, can be expected to find in his client's favor. This insincerity is quickly detected by the jurors. We lie to them and they in turn to us; this is a bad beginning for a project designed to discover the truth.

Most jurors come to court burdened with prejudices that can easily wreck the defense of a criminal case or the prosecution of a civil complaint. ${ }^{4}$ They are reluctant for these symptoms of their own bias to be confirmed publicly. Thus, the unmasking of bigotry is frustrated by a lack of candor on the part of most jurors. Impelled by a desire to be selected, they tend to shape their answers into what they believe to be socially acceptable responses. Anyone who has ever selected a jury in a highly celebrated case, where the whole community has been drenched in publicity adverse to the defendant, and who has listened to one juror after another disavow any knowledge of the case, knows how disheartening that can be.

A study, done by John Murray and John Eckman concerning the trial of

ought to keep it close at hand. Shattering traditional notions about picking a jury, this exceptional work has sent reverberations throughout the legal profession. For some of the critical response see Etzioni, Science: Threatening the Jury Trial, Wash. Post, May 26, 1974, at C3, col. 1; Kahn, Picking Peers: Social Scientists' Role in Selection of Juries Sparks Legal Debate, Wall St. J., Aug. 12, 1974, at 1, col. 1; Etzioni, Creating an Imbalance, 10 Trial 28 (1974).

There is also a large body of psychological literature useful for voir dire practice. See R. KaHN \& C. Canneli, The Dynamics of Intekviewing (195\%); S. Richardson et al., Interviewing, Its Forms and Functions (1965); R. Gordon, Interviewing: Strategy, Techniques, and Tactics (1975). Five additional articles are cited in GINGER, supra note 1, at 297-304. R. Gordon produced a mimeographed piece, "A Psychological Strategy for Jury Selection" (1973). California lawyer and medical hypnotist, William J. Bryan, contends that he can predict what a juror will do in the jury room eleven-twelfths of the time, merely on the basis of voir dire cues. See KaHN, supra, at 19 , col. 4.

3. The social science team approach focused on obtaining juries favorable to radical defendants, and its sometimes potent effects, is surveyed by Etzioni, Scientific Jury Stacking Puts Judicial System on Trial, Boston Globe, June 23, 1974. See also the articles by Saks, supra note 1; Etzioni, supra note 2: KaHN, supra note. 2.

4. Bennett, supra note 1. 
the "Camden 28,"5 revealed that a considerable portion of the jurors interviewed gave substantially different answers in private interviews, conducted after the trial, than those furnished during voir dire. ${ }^{6}$ A carefully conducted survey in the 1976, Joan Chesimar murder prosecution, in Middlesex, New Jersey, disclosed that 71 per cent of the community eligible for jury service had fixed opinions about her guilt. And yet, during a searching and skillfully conducted voir dire by counsel, only 15 per cent of the jurors admitted any form of predisposition. ${ }^{7}$ This disparity between the survey results and the uncovering of bias during the voir dire can be explained only by a lack of honesty on the jurors' part.

The simple truth is that prejudice is a staple in the jury box and most lawyers do not have the necessary equipment to deal adequately with it. Uprooting of intolerance of this unique constituency is beyond the appliances of the legal profession. Although these explosive forces cannot be defused by counsel, they must be located and identified. Lawyers must learn to pick the lock of these deep-seated prejudices if they are to secure a relatively impartial jury ${ }^{8}$ Consequently, jury selection in a criminal case taxes the talents of a trial lawyer enormously. No undertaking requires deeper professional commitment or greater preparation.

\section{II}

\section{A Systematic Approach}

Any sensible approach to choosing a jury requires a plan. Common sense dictates that the lawyer should have an idea of precisely what type of jury he wants for his case before jury selections begins. This "profile" will vary from one law suit to another. Factors that must be considered in deciding what kind of a juror is needed can range from the client's personality, to the makeup of the prosecution's witnesses, to the nature of the charge. A trial is a human enterprise and the jury tends to identify with the people who populate the case. Thus, jurors should be selected who will empathize with either the defendant, his witnesses, or even his attorney.

However, surface identities can be misleading. A middle-class black may be embarrassed by the actions of a black narcotics dealer. An Italian banker may despise a person of his own nationality who is accused of membership in that elusive group labeled "organized crime." A high ranking executive may wish to make an example of the broker who is charged with securities

\footnotetext{
5. United States v. Anderson, No. 602-71 (D.N.J. May 19, 1973).

6. Murray \& Eckman, supra note 1.

7. National Jury Project Study (1976) (available from National Jury Project, 853 Broadway, New York, N.Y. 10003).

8. See D. Kairys, The Jury System: New Methods for Reducing Prejudice (1975).
} 
fraud. Accordingly, counsel must be sensitive to the crosscurrents in any large city seething with antagonism. Ask the defendant how he feels about blacks, Italians, Jews or any other minority group that will make up a significant segment of the jury panel. His feelings may be representative of his minority and can be helpful in making important choices. Where possible, ask members of other minority groups how they feel about the class to which your client belongs.

Make a list of the prosecution's witnesses, if known, and analyze their race, nationality, age and other social traits. If a particular prosecution witness will play an important part in the case, jurors who identify with that witness should be avoided. The realization that two impressive black police officers will testify against a black defendant may have some influence upon the type of black jurors selected. An elderly complainant in a robbery case will appeal more to older jurors. Consideration must be given to these separate components.

Do not lose sight of your adversary's background and nationality. Irish jurors may yield more to an Irish prosecutor's arguments. A young, inexperienced prosecutor may have more appeal to young jurors who can sympathize with his failings, whereas a brash and aggressive prosecutor may offend jurors who are soft-spoken and genteel. These human features and many more must be considered.

The nature of the case has a significant impact upon certain members of the community. Religious persons must be avoided in obscenity prosecutions; wage earners are dangerous in income tax prosecutions; blacks who have seen the ravages of the drug trade in their community must be considered carefully in a narcotics prosecution; and young, idealistic jurors, or "limousine liberals," may be unacceptable in a political corruption case. Of course, generalizations are hazardous, but it is enough to say that a great deal of thought must be given to a host of factors. Finally, consider the defense witnesses who may be called in judging the kind of jurors you want. The nationality, complexion and social status of alibi or character witnesses must be calculated.

Make a list of all the favorable features sought in the ideal juror on one side of a sheet of paper and all the unfavorable features on the other side. Prioritize these features. An adequate inventory should include ten to fifteen features on each side. After the catalog is complete, study it diligently. If nothing else, this exercise will compel counsel to think clearly about what kind of a jury is desired. Knowing exactly what type of a juror is sought will improve the chances of achieving that objective.

To better organize the recording of the jurors' names and addresses, draw a diagram of the jury box with a square for each seat. A supply of these sheets can be kept in the lawyer's office and used when needed. 


\section{A. Purposes Of Voir Dire}

The voir dire has two objectives. The first is to enable counsel to gather sufficient information to make well informed judgments about jurors whose biases may interfere with a fair consideration of the evidence. The second is to familiarize the jurors with certain legal concepts and gain from the jurors assurances of fairness. " The latitude allowed in discussing the "law" with jurors varies from state to state. ${ }^{10}$ This critical area of inquiry is being fenced off by our courts more and more. ${ }^{11}$ Equally frightening is the clamor that the voir dire should be taken from counsel and conducted by the court, as in the federal system. This practice renders jury selection virtually meaningless. ${ }^{12}$

The chemistry that reveals a juror's true feelings can be generated only by confrontation. Without face-to-face inquiry, an intelligent choice of a juror is severely impaired. ${ }^{13}$ Furthermore, a juror's answer to one question may prompt inquiry into another area that can only be conceived of by the singlemindedness of counsel. A judicial officer who is "presumably" disinterested cannot conduct such an investigation effectively.

Most members of the bar do not object to a trial judge's insistence that the selection process be conducted expeditiously. Needless repetition of questions and dragging out the jurors examination not only alienates them, but endangers this privilege for all of us. Thus, in those communities where the privilege of speaking with jurors still exists, a sense of responsibility and good judgment among the bar should be encouraged.

In those places where the court conducts the voir dire, a motion should be made for an examination of the jurors by trial counsel. Explain in detail why

9. The indoctrination function of voir dire may be more effective than the screening function in courts where the judge disapproves of protracted examination of prospective jurors. See Broeder, Voir Dire Examinations: An Empirical Study, 38 CAl. L. Rev. 503 (1965). See also Babcock, Voir Dire: Preserving "Its Wonderful Power", 27 STAN. L. R. 545 (1975).

10. Suggestions and state-by-state comparisons are contained in Van Dyke, Voir Dire: How Should It Be Conducted to Ensure that Our Juries are Representative and Impartial, 3 Hastings Const. L.Q. 65 (1976).

11. Under Rule 24(a) of The Federal Rules of Criminal Procedure, the judge decides who will conduct the voir dire. A survey of eighty-five judicial districts reveals that the judge conducts the voir dire in fifty-one, the judge and the parties in twenty-two, and the litigants alone in twelve. The Jury System in the Federal Courts, 26 FRD 409, 466 (1961). In most state courts the parties are permitted to participate in jury selection. Statistics show that in twenty-two states the judge and the parties conduct the voir dire. In ten states the judge selects the jury; in eight states it is done exclusively by the parties; and in ten states it is discretionary with the judge. Annot., 73 ALR2d 1187 (1960); Comment to ABA Standards, Trial by Jury, Standard 2.4.

12. One study conducted by the well known psychologist, A. Padawer-Singer, showed that juries selected by lawyers, as compared to those that were not subject to any voir dire, were less easily swayed and more resistant to group pressure. They were also "more aware of the importance of legal procedures and admissible evidence." A. Padawer-Singer, Voir Dire by Two Lawyers: An Essential Safeguard, 57 JUdicature 386 (1974).

13. The pros and cons of lawyer-conducted voir dire are considered in Gutman, The AttorneyConducted Voir Dire of Jurors: A Constitutional Right, 39 BrookLyN L. Rev. 290 (1972); McGuirk \& Tober, Attorney-Conducted Voir Dire: Securing an Impartial Jury, 15 N.H.B.J. 1 (1973); and Note, Judge Conducted Voir Dire as a Time-Saving Trial Technique, 2 Rut.-Cam. L. J. 161 (1970). 
an interrogation of the jury panel by counsel will improve the chances of obtaining a fair trial. A respectable body of law supports the advisability of lawyers conducting the examination in an unfettered fashion. ${ }^{14}$ Provide the trial judge with sample questions that will dramatize the need for an individual inquest of the jurors. Ask for a hearing that will permit a full judicial investigation of your complaint. ${ }^{15}$ The court may accede to the defendant's application, but if it is rejected, an issue will be preserved for appellate review if necessary.

Recently, the science of survey research has been harnessed by defense lawyers in cases where the client can afford that service. The survey firm produces a "jury profile" that can be used to guide the trial lawyer through the treacherous shallows of jury selection in a controversial case. Such an investigation is usually initiated by designing a questionnaire which measures attitudes associated with the important trial issues and the personality characteristics of people who are sympathetic to the defendant's claims. Interviewers use these questionnaires to collect information from a random sample of the juror population. The interviewers do not approach prospective jurors. Through correlating the background characteristics with the behavior measures, it is possible to detect the important variables that predict the population's attitudes. It may be discovered, for example, that men are more favorable to the defense than women; young people more than the aged; liberal people more than authoritarians; readers of the New York Times more than readers of the New York Daily News; blacks more than whites; protestants more than catholics. It may be discovered that the level of education, introversion, age, political affiliation, and many other features are not related to the decisive opinions. ${ }^{16}$

The major benefit of obtaining demographic correlates of attitudes is that, although jurors may color their answers to specific questions during a voir dire, they cannot conceal their pedigree and background. Armed with this information, counsel can better plan questions for the prospective jurors. The National Jury Project is, by far, the most prominent organization specializing in this type of survey. However, other individuals and firms have entered this

14. Our courts have always acknowledged the importance of a voir dire conducted by counsel. Swain v. Alabama, 380 U.S. 202 (196.5); United States v. Blount, 479 F.2d 650 (6th Cir. 1973); United States v. Dellinger, 472 F.2d 340 (7th Cir. 1972); United States v. Lewin, 467 F.2d 1131 (7th Cir. 1972); Lurding v. United States, 179 F.2d 419 (6th Cir. 1950); Bailey v. United States, 53 F.2d 982 (5th Cir. 1931). See generally F. Busch, Law and Tactics in Jury Trials, §§ 81, 84, 93 (1959); 47 AM. Jur. 2d \$201.1, at 789 (1969); Bush, The Case for Expansive Voir Dire, 2 L. AND Psych. 9 (1978). But see Ham v. South Carolina, 409 U.S. 524 (1973) (holding that the fourteenth amendment required questions about race, but not about facial hair). United States v. Oscar Bear Runner, 502 F.2d 908, 910-12 (8th Cir. 1974). See also Nebraska Press Association v. Stuart, 427 U.S. 539 (1976), where the Supreme Court suggested an in-depth voir dire conducted by counsel to locate prejudice generated by adverse publicity.

15. United States v. McNeil, Cr. 73-0098 (N.D.Cal. 1973).

16. Saks, supra note 1. 
field and may be consulted. ${ }^{17}$ Survey costs range anywhere from $\$ 5,000$ to $\$ 20,000$, and up.

If the client cannot afford a professional survey, counsel can conduct a less comprehensive investigation. ${ }^{18}$ In virtually every jurisdiction, each juror has a corresponding "ballot" or "card" bearing his or her name, address and occupation. When a panel of fifty jurors is sent to a particular courtroom, the jurors' ballots are transferred to the court clerk. The clerk places them in a drum from which the jurors names are randomly drawn for placement in the jury box. Defense counsel should request to examine the jurors' cards before they are dispatched to the courtroom. This application is based upon a need to examine all the jurors so that counsel can be adequately prepared for their selection. Furthermore, in most jurisdictions, any complaint that the panel is not representative of the community at large, must be made before the selection process begins.

After receiving the ballots, counsel should make a list of the jurors with their names, addresses and occupations. This will provide a better portrait of the jury. The analysis will reveal how many men, women, blacks, Italians, or other groups make up the jury. Accordingly, counsel can better estimate the probability of getting certain kinds of jurors.

In some jurisdictions, a list of prospective trial jurors is published and distributed in advance of their term of service. A copy of this list should be obtained in advance of the trial and studied carefully. With more time available, a detailed breakdown of jurors' occupations, sex, nationality and race can be plotted. These vital statistics help the trial lawyer better plan the choice of jurors he will ultimately make. Sometimes a particular strain of an ethnic group will, by circumstance, dominate a pool. Discovery of a high ratio of Germans or Hispanics in the panel is valuable in planning the approach to jury selection.

\section{B. Extra Peremptory Challenges ${ }^{19}$}

Convention conspires against the defendant in a criminal case. Two-thirds of most jury panels are unsympathetic to the defendant. The National Jury

17. Dr. Charles Winick, 160 Riverside Dr., New York, N.Y. 10024; Roger Seasonwein Associates, 2 West 45th St., New York, N.Y. 10036; Dr. Alice Padawer-Singer, 130 East 67th St., New York, N.Y. 10021.

18. Using basic sociological methods, a defense lawyer, working with an expert statistician, can undertake a demographic survey by telephone and mailed questionnaires. GinGER, supra note 1 , at 126-27, 199. Schulman, supra note 1 , declares that a good survey can be put together for as little as $\$ 500$. Useful material on conducting a community survey and challenging the jury panel is compiled in KaIRys, supra note 8. J. Rose, The Use of Surveys in Jury Selection: Some Methodological Considerations (an unpublished paper by The National Jury Project).

19. D. Kairys demonstrates the integration of mathematical formulas into the legal work of jury challenges in Juror Selection: The Law, a Mathematical Method of Analysis, and a Case Study, 10 Aм. Crim. L. R. 771 (1972). A more detailed explanation of these methods for calculating and proving non-random selection is provided in Finkelstein, The Application of Statistical Decision Theory to Jury Discrimination Cases, 80 HARv. L. REv. 338 (1966). 
Project has done the most authoritative research in the field of jury dynamics. Its findings show that 25 percent of the people selected for jury duty believe that an accused person is guilty, otherwise he would not have been charged. Thirty-six percent believe that it is the defendant's responsibility to prove innocence, rather than the state's duty to prove guilt. ${ }^{20}$

In light of this disadvantage, it is imperative that counsel make a motion for additional peremptory challenges. ${ }^{21}$ In most jurisdictions, the judge has authority to grant this relief. If this crucial imbalance in the panel is not corrected, the defendant is placed at a distinct disadvantage.$^{22}$ Express in detail the need for extra challenges by identifying the sectors of bias the defendant will encounter among jurors. A survey of the community showing a high level of aversion toward the defendant will lend force to this application. Most courts are sympathetic to the defendant's handicap in this area and will grant some relief. ${ }^{23}$

\section{Use Of Checklist}

A thorough examination of the jurors must include every relevant topic of inquiry in order to gain the necessary knowledge to make an enlightened choice. A checklist of the areas of interrogation should be used. A catalog of subjects to be covered ought to include:

1. Family status

a) Number of children, ages and sex?

b) Spouse employment, if any?

c) Reside with parents?

2. Residence

a) Do you own your home, or rent?

b) How long have you lived at your present address?

20. Statistics obtained from the National Jury Project, 853 Broadway, New York, N.Y. 10003.

21. The significance of additional peremptory challenges for the defense is chronicled in Zeisel \& Diamond, The Jury Selection in the Mitchell-Stans Conspiracy Trial, 1 Am. B. Foundation ReSEARCH J. 151, 157-60 (1976).

22. Significantly, defense counsel in a criminal proceeding is given more challenges than the prosecutor in federal courts and in twenty states. The states that allow more challenges to the defendant than to the district attorney are: Alabama, Alaska, Arkansas, Georgia, Kentucky, Maryland, Minnesota, Missouri, New Mexico, North Carolina, Oregon, South Carolina, Tennessee, West Virginia (in all felony and capital cases, but not in misdemeanor trials); Michigan, Nebraska (in cases with a penalty of death or life imprisonment); Delaware, Maine, New Hampshire (in capital trials only). J. VAN DYKE, supra note 1, at 282-83.

23. Extra peremptory challenges were granted to the defense in the following cases, United States v. Olin, N. 78-38 (W.D.N.Y. 1979) (2); United States v. Goldfarb, N. 8-80572 (E.D. Mich. 1979) (14); United States v. Sturman, (N.D. Ohio 1976) (14); Commonwealth v. Saxe, No. 51775 (Suffolk Co. Mass. Super. Ct. 1976) (10); State v. Means, No. 11826 (S.D. Cir. Ct. 1976) (10); United States v. Mitchell, Nos. 75-1381, 75-1382, 75-1384, 76-1441 (D.C. Cir. 1976) (5); United States v. Ehrlichman, No. 74-1882 (D.C. Cir. 1976) (5); United States v. Means, 409 F. Supp. 115 (D.N.D. 1976) (16); People v. Hill \& Pernesalice, (Erie Co., N.Y. Sup. Ct. 1975) (10); United States v. Means, (3rd Div. Minn. 1973) (10); United States v. Anderson, No. 602-71 (D.N.J. 1973) (15); United States v. Ahmad, No. 14950 (M.D.Pa. 1971) (18). 
c) How many places have you lived in the past ten years?

d) Do you own other real estate?

\section{Occupation}

a) What kind of work do you do?

b) If you have a job title, what is it?

c) In your job, do you have the authority to: promote people; hire people; fire people?

d) How many people do you supervise, or how many people report directly to you in your job?

e) How many different employers have you worked for in the past ten years; name them?

f) If your spouse works outside the home, what does she or he do?

4. Education

a) How far did you go in school?

b) Have you done postgraduate work?

c) If so, at what school and what degree did you receive?

d) What subjects did you major in while in college?

e) Did you participate in athletics or extracurricular activities?

5. Prior jury service
a) Civil?
b) Criminal?
c) Were you juror foreman?
d) If a verdict was reached, what was it?
$e$ ) Grand jury service?
f) Membership in Grand Jury Association?

6. Relationship with law enforcement agencies

a) City, state, federal police?

b) Prosecutors?

c) Internal Revenue Service, Immigration, and other quasi-law enforcement agencies?

d) Military police?

$e)$ Know any lawyers?

7. Victim of Crime
a) Appearance before grand jury?
b) Meetings with District Attorney?
c) Testified at trial?

8. Experience with justice system
a) Ever been a witness?
b) Ever been an investigator?
c) Ever a party to litigation? 
9. Publicity
a) What newspapers or magazines do you subscribe to?
b) Have you read anything about this case?
c) Do you know anything about this case?
d) Do you know anyone connected with this case?

10. Military Service
a) What branch?
b) What rank?
c) Were you ever in combat?
d) Military police?

11. Organizations
a) Civic?
b) Religious?
c) Political?
d) Social?
e) Union?
f) Scouting, PTA, CYO, YMCA, YWCA, etc?
g) Ever held office in organizations?

12. Leisure Time
a) Hobbies?
b) Favorite television show?
c) Drink alcoholic beverages, or visit night clubs?
d) What is the last book you read?

13. Special Issues
a) Alibi
b) Self-defense
c) Lack of intent
d) Involuntary statement
e) Insanity
f) Intoxication
g) Entrapment
h) Recantation
i) Justification
j) Duress
k) Renunciation

14. Legal Principles

a) Presumption of innocence

b) Proof beyond a reasonable doubt

c) Circumstantial evidence

d) Separate verdicts for each defendant 
e) Elements of crime charged

f) Character evidence

This list is extensive, but it is by no means complete. ${ }^{24}$

Unless counsel is endowed with an infallible memory, the list of questions to be asked of prospective jurors must be outlined on a legal pad so that those topics can be reviewed periodically. Failure to ask one important question, such as, "Do you know any police officers?" can be ruinous. Jurors are obliged only to answer those questions put to them.

On the other hand, to be effective with the jurors, counsel should avoid the use of notes as much as possible. Being "pad bound" is distracting to the jury. A good trial lawyer wants to establish eye contact with the jurors in the early stages of the trial. A helpful memory technique, called the link system, is explained in The Memory Book. ${ }^{25}$ Arranging your questions in an order that follows a daily routine helps you to remember them. For example, if you think of getting up in the morning and meeting your family for breakfast, that will remind you to ask the juror about her family. The following Table illustrates how the system works.

TABLE I

THE LiNK SySTEM

Links

Breakfast with family

Leaves for work and drops children off at school

Stops at work

Stops at newsstand on way to courthouse

Meets police officer outside courthouse

Passes grand jury room in courthouse

Passes jury pool

Enters courtroom
Question To Be Asked Of Juror

- Ask about family

- Inquiry about educational background

- Ask about occupation, union, number of people supervised

- Ask about publicity and reading habits

Questions about law enforcement officers, prosecutors, victim of crime

- Ask about prior grand jury service

- Ask about prior jury service

- Ask about experience as witness or investigator

24. For a more expansive index of subjects to be covered in a variety of criminal prosecutions see Ginger, supra note 1 , at 372-442; see also National Jury Project, Jury Work: Systematic TECHNIQUeS, supra note 1.

25. L. Lorayne \& J. Lucas, The Memory Book (1974) 
Commences service as juror

Goes home at end of day and plays with children
- Ask about all legal propositions

- Ask about hobbies

This simplified version of the link system can be expanded to cover a variety of special situations. Despite the use of such memory aids, keep a written list of questions available so that in moments of confusion, the more reliable source can be checked to make sure that every subject is covered.

A lawyer's greatest enemy is habit. Each trial case involves different considerations. The selection of a jury cannot be followed by rote. Each case must be thought out. Every jury must be chosen differently. Thus, many questions should be added to the foregoing list in order to meet the special needs of any given case. For instance, in a perjury case, concepts of truthfulness must be discussed. The defense of a lawyer mandates an intensive inquiry into feelings about the legal profession and a juror's experiences with lawyers. The trial of a public figure requires asking about political involvements and attitudes toward politicians. These special areas of inquiry are limited only by the boundaries of an attorney's imagination. In an article of this size there is no way every problem confronting a lawyer who is obliged to select a jury in a criminal case can be anticipated. Let it suffice to say that picking each jury is unique and involves different elements that must be thought out carefully.

\section{Observation of Jurors}

Jury selection begins the moment counsel enters the courthouse. He must be observant. ${ }^{26}$ Jurors usually stand out because of their apparent unfamiliarity with the courthouse. Watch what they do and try to remember their faces. Note what they say in the lobby of the courthouse, how they behave, what newspapers they buy; these activities will reveal in a small way what they are like. When the jury panel is brought into the courtroom, study them. Search for clues that may be helpful in making important choices. A Wall Street Journal tucked under an arm, a sexy paperback book protruding from a purse, or a best-seller in a juror's hands can be meaningful.

Remember those jurors who are friendly and talking to others. Make a note of those who stay to themselves and talk to no one. If you listen closely, sometimes complaints about the jury selection system can be overheard. These discoveries can be portentous. Look for obvious friendships that have formed. If one of the pair is excused by defense counsel, when his or her friend appears in the jury box, the remaining person may be antipathetic toward counsel who excused the friend.

26. Cultivation of the art of observation is encouraged. See the summary of T. Koskoff's speech to the ATLA (GINGER, supra note 1, at 480); Katz's description in The Twelve Man Jury, 5 TriAl 39 (Dec.-Jan. 1968-69); Schulman, supra note 1 , at 16 
During this important stage of the proceedings, a client must be reminded that while in the courthouse, he is "on camera" all the time. Jurors are inquisitive about him, as well as his lawyer, and he cannot escape their curious eyes. One thoughtless, rude act can make a bad impression that may damage the case immeasurably.

\section{E. The Judge's Remarks to the Jury}

In many jurisdictions, the judge will introduce the case to the jury by explaining its nature and presenting the participants. The court will usually welcome help in describing the nature of the litigation to the jury. This is particularly true in a controversial prosecution. If the case has some very unattractive aspects, from the public's viewpoint, it may be well to have the judge emphasize those bad features. Prepare a statement of the case from the defendant's viewpoint and ask the judge to read it to the jury. Suggest, in an effort to save time, that the court ask whether any jurors with reservations about a special aspect of the case would prefer to be excused. This invitation, coming from a judicial officer, may inspire some jurors to exempt themselves from service who would not be prone to do so under counsel's examination and after they have become more self-righteous.

The court's suggestion that the trial may last four or five weeks will have the effect of eliminating many young working jurors who cannot afford such a large time investment, whereas older, retired jurors can endure a longer tenure of service. This action will decimate the jury and leave the old, the jobless, and the poor. Unless counsel finds this class of jurors attractive, an objection must be raised immediately.

\section{F. The Voir Dire}

Make certain that the voir dire is transcribed. In most courts, jury selection is not recorded. Without a record, important issues raised during this critical stage of the trial may be lost.

After the twelve jurors are placed in the jury box, the prosecutor usually speaks to them first. While he is talking to the jurors, counsel should study them carefully. Do not hesitate to move your chair close to the jury box so you can hear the prosecutor's questions and the juror's responses. Make careful notes of how each of the jurors answer the district attorney's questions.

It is helpful to use a shorthand system of recording essential information supplied by the jurors. ${ }^{27}$ Defense lawyers have the advantage of listening to the prosecutor ask the jurors about their occupation, marital status, number of children, prior jury service, and a number of other topics dealing with the juror's pedigree. The following abbreviations may be useful:

27. An alternative system, with key, is given in GiNGER, supra note 1, at 507-08. 


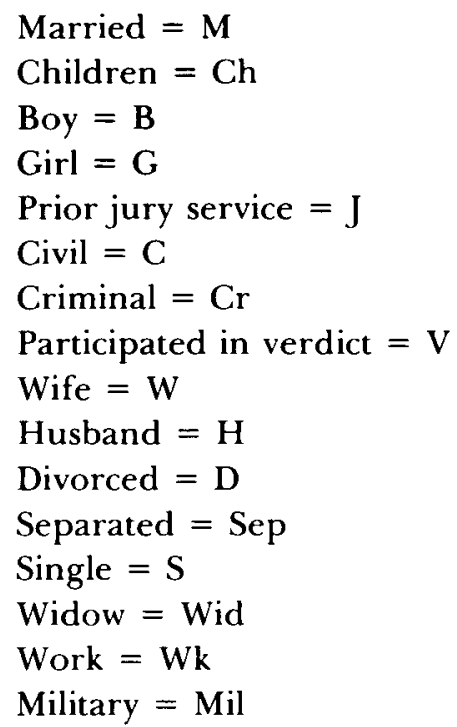

A juror who is married, with two sons and one daughter whose ages are fourteen, twelve and eight would be recorded: $M ; 2 B=14,12, G=8$.

A juror who has previously sat on one civil case, in which no verdict was reached and two criminal cases resulting in a verdict, will appear as: $1 \mathrm{C} ; 2 \mathrm{Cr}$ $=2 \mathrm{~V}$.

A juror who has worked as a machinist for twelve years at the $\mathrm{A}$. W. Bolt Co., and is a supervisor will read: WK $=$ Mach. $=$ A.W. Bolt $=$ Super. 12.

If the juror's wife does not work outside the home, she can be listed as "Hw" for housewife. If she has worked as a receptionist at a doctor's office for five years, this will be recorded: $W=W k=$ Recp. Dr. Off. $=5$.

Developing a shorthand system will enable counsel to record information quickly and accurately. While transcribing this information, give the juror an acceptability grade based upon your first reaction. This crucial entry must be made in code because of the risk that it may be inadvertently observed by the district attorney.

Recording this information should not be squeezed into the jury chart which is designed to simply hold the names and addresses of the jurors seated in the jury box. Use a standard legal pad and allocate a separate page for information on each juror. This technique allows sufficient room for additional comments or information. If a juror is excused you can remove that page. $\mathrm{Be}$ sure to keep careful record of your challenges. As the prosecution nears the point of exhausting his challenges, check with the court clerk to make certain the final count is accurate.

Chances are, when the district attorney finishes his inquiry, counsel will know which jurors he wants to excuse. A few marginal jurors will require further examination. However, each juror must be examined carefully to confirm or alter the original impression. 


\section{G. Opening Remarks to the Jury}

Defense counsel's opening remarks to the jurors should not be made from behind a podium. Get close to the jurors. Do not allow anything to come between you and them. If the defendant's family is in the courtroom, counsel may wish to introduce them to the jury in order to find out whether any of the jurors know them. Then address the twelve jurors collectively and impress upon them the importance of this phase of the trial. Explain to them that they are going to be called upon to make the most important decision that they will render in this case (with the exception of their final verdict, if chosen). That decision is whether they can sit on the case and be completely fair and impartial. Advise them that your task is to help them make that choice by bringing to their attention possible experiences that could unduly influence their judgment. Point out to them, as an example, that a close relationship with a police officer may make it difficult for them to be impartial since members of that department will testify for the prosecution. Stress that there are no "right" or "wrong" answers and that frankness is the key to succeeding in this part of the trial. Tell them that the term voir dire means "to speak the truth," and you ask no more of them than that. Once the tone of jury selection has been set, examine individual jurors.

Picking a jury can be expedited without sacrificing thoroughness by asking the entire panel a number of questions. Such inquiries include unique experiences; for example, an inquiry concerning prior grand jury service, experience as a witness, or military service. A juror who acknowledges that he has served on a grand jury or was in the military service can be examined on that subject more thoroughly during individual voir dire. Remember, the longer you talk with the jurors, the greater the risk of forfeiting their good will. Although the risk of some impatience must be assumed, everything should be done to minimize their boredom.

\section{H. Getting the Jurors to Talk}

Once you begin speaking with the individual jurors (and not to them), it is important that the juror be encouraged to talk as much as possible. Begin with nonthreatening questions concerning the juror's occupation, marital status, children, and education, which will relax the juror. Someone said that the primary index of a person's intelligence is diction. The more a juror talks the better you will come to know him or her. A series of "yes" or "no" answers help little. Ask "open ended" questions, rather than "closed" questions. For example, ask, "How far did you go in school?" rather than, "Did you attend college?" Ask, "What is your marital status?" rather than, "Are you married?" Where permitted, ask, "How do you feel about the presumption of innocence?" rather than, "Do you agree with the proposition that a defendant should be presumed to be innocent?" The latter question usually gains little 
more than a straight-faced assurance that is of no value; whereas, the former question should unlatch the juror's thinking on this critical subject.

In the same fashion, ask, "What does the concept of proof beyond a reasonable doubt mean to you?" rather than, "Do you agree that the prosecution must prove the case beyond a reasonable doubt?" The so-called, "How do you feel" questions are limitless. For instance, you may want to ask:

How do you feel about Billy Williams as he sits here in this courtroom right now?

Do you have any feelings about him at all?

How do you feel about police officers?

How do you feel about citizens being allowed to own guns?

What does the phrase, "My Government right or wrong," mean to you?

How do you feel about lawyers?

Try to start your questions with "How" and "What" rather than "Do you agree," or "Do you believe." There are occasions when you must ask, "Do you believe the actions taken by the FBI are always right?" or "Do you believe that police officers can make mistakes?" Obviously, a yes or no answer to these questions can be instructive, but the majority of the questions should be "How do you feel" ones.

Ask the jurors in detail about their occupations by inquiring, "Tell me, Mr. Jones, specifically what do you do as a salesman?" If the answer to that question is not expansive enough, ask, "Can you tell me on a given day what you do from the time you start work until the time you finish?" Every question should be structured to prompt as complete an answer as possible.

\section{Judging Jurors' Reactions}

Despite the emphasis placed on candor, many jurors strive to give answers they think are correct or are pleasing. Consequently, the way they answer the questions is often more important than what they say. Study their reactions carefully. Questions should be developed that will explore their feelings rather than their words. For instance, when inquiring about the presumption of innocence, consider this technique:

Q. How do you feel about the presumption of innocence?

A. I think it's a good rule, and it should be followed.

Q. Mr. Jones, I'm going to ask you to do me a favor. Will you look at my client, Billy Williams, right now and tell me whether you can honestly think of him as being innocent?

At that instant, concentrate on the juror's face. If he has difficulty looking at your client or, when he glances at him, he drops or narrows his eyes, rejec- 
tion is evident. The expression on the juror's face at that moment will tell you all you need to know.

Beware of the juror who gives qualified answers. For example, the juror, asked whether he could follow the rule of proof beyond a reasonable doubt, answers, "I will, if the judge tells me that's the law," is obviously distrustful of counsel's version of the rule. The juror is asked whether she could vote not guilty if the prosecution failed to prove the case beyond a reasonable doubt and answers, "I would have to hear all the evidence before I could say," is resisting an affirmative response. Qualifying phrases such as: "I think so," "I guess I could," "I'll try," are indications of "No." Weak speech is exemplified by the use of hedges, such as, "It seems like," "kinda," "sort of."28

After response, some jurors will look unconsciously to the district attorney or the judge for either approval or reassurance. Other jurors will find it hard to look at you or the defendant. This "gazing behavior" can be informative. These movements of a juror replace speech. On occasion, gestural information can speak more eloquently than words. ${ }^{29}$ Questions must be sharpened like a scalpel to cut through the jurors' callous pretenses and affectations in order to reach the core of their personalities.

Behavioral engineers tell us that human communicative conduct can be classified in three dimensions: verbal, paralinguistic, and kinesic. ${ }^{30}$ For instance, social researchers find that people talk longer with those toward whom they have positive emotions. ${ }^{31}$ Thus, keeping track of the amount of time a prospective juror spends speaking with the district attorney or defense counsel may tell with which side he or she feels more at ease. Excessive hand movement, such as tapping the fingers on a thigh, interwining them, or excessive activity, reflects a juror's anxiety. This may indicate discomfort with the attorney examining the juror. The large body of research in this area should be read by trial lawyers.

\section{J. Jurors' Hobbies}

Another effective method of gaining insight into the true personality of jurors is to ask them what they do in their spare time. A juror's hobbies can

28. H. Bodin, Civil Litigation and Trial Techniques 258 (1976); Connolly, O'Barr \& Lind, The Power of Language Presentational Style, 1978 Duke L.J. $1375,1380$.

29. See M. Lafrance \& C. Mayo, Moving Bodies: Nonverbal Communications in Social Relationships (1978); N. Henley, Body Politics (1977); J. Fast, Body Language (1970).

30. Höweler \& Vrolijk, Verbal Communication Length as an Index of Interpersonal Attraction, 34 Acta Psychologica 511,514 (1970); Wiens, Jackson, Manaugh \& Matarazzo, Communication Length as an Index of Communicator Attitude: A Replication, 53 J. Applied Psych. 264 (1969). Paralinguistics is defined as that aspect of speech dealing with breathing, pauses, pitch and tone of voice, as well as speech disturbances. Kinesic behavior, or body language, consists of such physical activity as facial expressions, body movements, body orientation, eye contact and hand movement.

31. See Suggs \& Sales, supra note 1; see also Pittenger \& Smith, A Basis for Some Contributions of Linguistics to Psychiatry, 20 Psych. 61, 69-74 (1957). 
be instructive. A person who belongs to a gun club and likes to shoot animals tells us one thing. A person who collects stamps or coins tells us something else. Engineers, scientists, accountants, and bookkeepers are, for the most part, unemotional. ${ }^{32}$ They are trained to be objective and reach conclusions based upon facts. They would be unsuitable in a case where the defense relies upon a heavy emotional appeal, but might be acceptable in a case where the prosecution depends upon sheer circumstantial evidence unattested to by hard facts. A bank teller who plays in a rock band on weekends may be more acceptable than his occupation would imply. Learning about a juror's favorite television program can be telling. Inquiries of this type are designed to slip by the juror's defenses and reach his true feelings.

\section{K. Other Areas Of Inquiry}

Try to convert jurors to your cause by simplifying the issues and discussing them in terms they will understand. In an identification case, ask whether a juror has ever had the experience of seeing someone he thought he knew and then later learned it was the wrong person. In a "bad check" case, ask a housewife whether she has had the unhappy experience of innocently issuing a check and later learning there were insufficient funds in her account. In a perjury trial, ask a businessman whether or not he has recalled an event differently than his secretary. Then ask him, when he told someone else that the meeting occurred on the wrong day, whether he intended to mislead them. In this way, jurors become directly involved in the defense and can better understand it.

Do not be afraid to develop the unattractive features of your case with the jury. A confession or criminal record that is bound to be received in evidence must be discussed. Present the issue as gracefully as possible and ask each juror if he or she can follow the law relating to that question. Where only one witness will condemn your client and he or she has received immunity, develop the "deal" with the jury. Explain to them the benefits the witness has received and tell them of his obvious motive to incriminate your client. This can be accomplished by asking them if they would be willing to apply the law as it relates to credibility of witnesses.

Defense lawyers differ in their views about whether to disclose to the jury that the defendant will not take the stand. Most lay people misinterpret the invocation of the privilege against self-incrimination as an admission of guilt. Thus, this relevation, at the beginning of the trial, involves grave risks. First impressions are important. If the trial begins with the jury believing that the

32. M. Blinder, Psychiatry in the Everyday Practice of Law \$27, at 52 (1973 Supp.); Kennelly, supra note 1; Busch, Observations as to the Manner and Scope of Examination of Prospective Jurors, 9 Trial LAw GuIde 81 (1965) and Vance, Voir Dire Examinations of Jurors in Federal Civil Cases, 8 VILl. L. REv. 76 (1962). 
defendant will not testify, you may lose and never regain their confidence. Another approach is to speak of the presumption of innocence and the principle that a defendant in a criminal case does not have to prove anything. Inquire of the jurors whether or not they can follow that precept. In this way, the foundation is laid for the defendant resting at the end of the prosecution's case. This somewhat surprising event will come after the defense has already done a great deal of damage to the prosecution's case through crossexamination. The dissappointment experienced by the jury, in not hearing the defendant, is more easily handled later in the trial.

Finally, ask one last question of each juror that protects the defendant against harmful information possessed by the juror which may have been omitted. Ask, "Are there any reasons, which I may not have touched upon, why you could not sit on this case and give the benefit of your judgment?"

\section{Exercising Challenges}

The final choice concerning which jurors will be kept is the most agonizing part of jury selection. There are those jurors, who bear extreme characteristics, that both sides know will be removed. The police officer's brother and the flower child will be among the first casualties in the striking process. The jurors left possess features appealing to the state and the defense. These are the hard choices. Thus, the "alpha" factor is an element that must be carefully considered.

The alpha factor has emerged as an important symbol in the psychodynamics of jury selection. The alpha factor describes those strong human qualities which cause certain jurors to succeed in establishing their own territorial imperatives in the jury room. A juror favorable to the defense side with a high authority quotient may insure success, whereas a juror antipathetic to your client with a similarly high alpha factor may guarantee defeat. Age, gender, education, social status and the number of persons a juror supervises are features that contribute to the juror's authority factor. ${ }^{33}$ For example, a bank executive with fifty employees under his supervision is bound to have a higher alpha rating than a maintenance man who sweeps classrooms in a public school. The maintenance worker will probably defect to the stronger side, where the bank executive may convert a majority of the jury to his view. Thus, the authority rating is one of the most important considerations in deciding whether or not to retain a juror. Counsel can afford to pad the jury with weak people because they will not exercise much influence in the jury room. However, a juror with a high alpha factor, of whom one is unsure, should be excused because of the risk that such a person may exercise a dis-

33. R. Brown, Authoritarian Personality, Social Psychology (1965); Robinson \& Shavers, Measure of Social Psychological Attitudes (1969). 
proportionate amount of authority in the debating process. On the other hand, a benign juror, of whom one is uncertain, may be left on the jury with safety. Leadership qualities are obvious to most of us. Jurors who have occupied an office in a garden club, union, service club, or fraternal organization are accustomed to exercising authority and, therefore, usually have a high alpha factor. A person who has held a rank in the military, as master sergeant or captain, is used to giving orders and is a good candidate for the office of jury foreman. Questions should search for experiences that disclose a juror's exercise of control over others. Perhaps the most important question that can be asked during jury selection to detect this quality is, "How many people do you supervise?"

A person who answers questions with "Yes, sir" or "No, sir" is usually deferential to authority and may yield more to the power wielded by the prosecutor. Normally, softness of voice and shyness indicate that the juror will play a modest role in the jury's ultimate verdict.

Although it is risky to generalize, in most criminal cases the defense is looking for jurors with fewer social ties. Someone once said that the average defendant wants a juror who is unemployed, unattached, and unintelligent. That may be an exaggeration, but certainly the surveys conducted by such groups as the National Jury Project reveal that young people who are single and not deeply rooted in the community are best for the defense. Older people, entrenched in the establishment, will identify quickly with the prosecution and normally find in his favor. They feel more threatened by the defendant than the young.

Be wary of veteran jurors. It is easier for people to convict when they have done it before. On the other hand, jurors who have acquitted in the past are sometimes told unfavorable things about the defendant by the prosecutor that were not developed during the trial. This form of contamination will spoil a juror for the future.

Although instincts are sometimes unreliable, bear in mind the advice given by an experienced trial lawyer, who said, "If you don't like a juror's face, chances are he doesn't like yours either-and you'd better get rid of him." If you have an uneasy feeling after talking with a prospective juror, excuse him or her.

\section{Challenges For Cause}

Do not give up too easily on challenges for cause. Where a juror has a clearly defined bias, but continues to protest that he can be fair, seek a hearing before the judge. Carry to court a brief prepared on the law governing challenges for cause. In New York, the case of People v. Culhane, is useful. ${ }^{\mathbf{4}}$

34. People v. Culhane, 33 N.Y.2d 390, 350 N.Y.S. 2d 381, 305 N.E.2d 469 (1973). 
In Culhane, the New York Court of Appeals said, in unmistakable language, that it is better for a court to err by excusing the juror, where there is doubt, rather than letting the juror sit with the risk of affecting the integrity of the verdict in the event a conviction follows. The common sense of this argument would seem to apply in any jurisdiction.

\section{III}

\section{ConClusion}

We, who are hired to speak for others, face our greatest challenge when called to defend a person charged with a serious crime. We owe him our best at that critical moment when he faces the most terrifying sanctions that can be imposed by any civilized society. Since the selection of those who will ultimately decide the defendant's fate is by far the most important part of any criminal prosecution, we must devote ourselves to the task of improving our skills for this selection. It has been said that the jury selection is a journey into madness that ends in a quagmire of guesses and speculations. Trying to predict what a juror will do is like looking through a glass darkly. Nevertheless, we must try to master every technique that will help us achieve our objectives efficiently and effectively. Those of us who are unable to master the techniques used in the sorcery of jury selection can take comfort in the adage, "[i]n the valley of the blind, the one-eyed is king." 35

35. Erasmus, quoted in Popular Quotations for All Uses (1942). 